\title{
Impact of façade window design on energy, daylighting and thermal comfort in nearly zero-energy houses
}

Vanhoutteghem, Lies; Skarning, Gunnlaug Cecilie Jensen; Hviid, Christian Anker; Svendsen, Svend

Published in:

Energy and Buildings

Link to article, DOI:

10.1016/j.enbuild.2015.05.018

Publication date:

2015

Document Version

Peer reviewed version

Link back to DTU Orbit

Citation (APA):

Vanhoutteghem, L., Skarning, G. C. J., Hviid, C. A., \& Svendsen, S. (2015). Impact of facade window design on energy, daylighting and thermal comfort in nearly zero-energy houses. Energy and Buildings, 102, 149-156. https://doi.org/10.1016/j.enbuild.2015.05.018

\section{General rights}

Copyright and moral rights for the publications made accessible in the public portal are retained by the authors and/or other copyright owners and it is a condition of accessing publications that users recognise and abide by the legal requirements associated with these rights.

- Users may download and print one copy of any publication from the public portal for the purpose of private study or research.

- You may not further distribute the material or use it for any profit-making activity or commercial gain

- You may freely distribute the URL identifying the publication in the public portal 


\section{IMPACT OF FAÇADE WINDOW DESIGN ON ENERGY, DAYLIGHTING AND THERMAL COMFORT IN NEARLY ZERO-ENERGY HOUSES}

Lies Vanhoutteghem ${ }^{1,2, *}$, Gunnlaug Cecilie Jensen Skarning ${ }^{1}$, Christian Anker Hviid ${ }^{1}$, Svend Svendsen ${ }^{1}$

Link valid until July 26: http://authors.elsevier.com/a/1R9EX1M7zGitpw

* Corresponding author. Tel. +45 9940 2347. E-mail address: 1va@sbi.aau.dk (L. Vanhoutteghem).

1 Technical University of Denmark, Department of Civil Engineering, Brovej, Building 118, DK2800 Kgs. Lyngby, Denmark.

2 Present address: Danish Building Research Institute, Aalborg University Copenhagen, A.C. Meyers Vænge 15, DK-2450 Copenhagen, Denmark. 


\begin{abstract}
Appropriate window solutions are decisive for the design of 'nearly zero-energy' buildings with healthy and comfortable indoor environment. This paper focuses on the relationship between size, orientation and glazing properties of façade windows for different side-lit room geometries in Danish 'nearly zero-energy' houses. The effect of these parameters on space heating demand, daylighting and thermal environment is evaluated by means of EnergyPlus and DAYSIM and presented in charts illustrating how combinations of design parameters with minimum space heating demand can be selected within a solution space defined by targets for daylighting and thermal comfort. In contrast with existing guidelines, the results show an upper limit for energy savings and utilisation of solar gains in south-oriented rooms. Instead, low U-values are needed in both north- and south oriented rooms before large window areas lead to reductions in space heating demand. Furthermore, windows in south-oriented rooms have to be carefully designed to prevent overheating. Design options for prevention of overheating, however, correspond well with options for low space heating demand. Glazings with solar control coating are therefore obvious alternatives to dynamic solar shadings. Regarding room geometry, deep or narrow southoriented rooms show difficulties in reaching sufficient daylight levels without overheating.
\end{abstract}

Keywords: nearly zero-energy houses, fenestration, thermal indoor environment, daylighting, window size, glazing properties, geometry factors. 


\section{Introduction}

As part of European energy strategy and policy for reducing the use of fossil fuels, all new buildings are required to have a 'nearly zero' energy consumption in 2020 [1]. This creates a strong need for research in cost-effective technology and solutions that will help meet these ambitious energy reductions without compromising on daylight conditions and indoor climate. It is well-known that windows have a considerable effect on both energy consumption and indoor environment. For example, where large windows allow for more daylight in a space, they might also result in visual discomfort and excessive heat gains or losses which affect the energy needed for heating or cooling and the thermal indoor environment. So it is important to find a balance between daylight availability, thermal comfort and energy consumption if we are to achieve both the goal of a 'nearly zero' energy consumption and buildings with a healthy and comfortable indoor environment. There have been many studies on window design with regard to energy consumption for heating, cooling and lighting in office buildings. Studies carried out by Susorova et al. [2] and Ghisi and Tinker [3] focused on the effect of room geometry, window size and orientation on energy use for heating, cooling and lighting for office buildings in various climate zones. A study by Lee et al. [4] examined the effect of window-to-wall ratios, orientation, Uvalue, g-value and visual transmittance to find optimal window designs for office buildings in 5 typical climate zones in Asia. Similarly, Motuziene and Juodis [5] investigated the effect of window-to-wall ratios, window orientation and glazing type on the total building energy consumption for an office building in the cool climate zone of Lithuania, while a study conducted by Ko [6], explored ways of optimising daylighting and energy savings by performing simulations to find the best combination of window area and glazing properties for office buildings in six different climates in the U.S.

Due to the less predictable usage and occupancy in residential buildings, the link between energy consumption, thermal environment and daylighting is less obvious in residential buildings than in commercial buildings. Furthermore, while in office buildings most energy is used for cooling and lighting, in residential buildings there has been a historical focus on reducing the energy needed for heating. These might be reasons why, the topic of the integrated evaluation of window design and its combined effect on heating, cooling and lighting has been less explored in residential buildings. A number of studies on the topic of lighting in residential buildings have evaluated daylight availability and the potential for savings in artificial lighting with various geometries and window sizes [7-9]. Studies on reducing the heating and cooling demand in residential buildings have considered the influence of window orientation, size and glazing type and suggested that south-facing window size is important for reducing heating demand [10-13]. However, a study by Persson et al. [14] on the performance of passive houses in Sweden has shown that window size is not that important any more for the reduction of heating demand. In well-insulated residential buildings, the focus should be on reducing the risk of overheating. 
Recently, there has been renewed attention on the thermal indoor environment and potential nonvisual effects of daylighting in residential buildings [15] as part of a movement towards sustainable buildings with a focus on user well-being [16]. 'Active houses' [16] should be designed, for example, so that they allow for optimal daylighting and attractive views to the outside while ensuring a good thermal indoor environment and low energy consumption without having negative impact on the environment. Following the Active house specifications [17], a house called 'Home for life' was designed and constructed in Denmark as part of the Model Home 2020 project, which has the aim of developing climate-neutral buildings with a high level of livability [18]. The house has a window-to-floor ratio of $40 \%$ to achieve an average daylight factor of 5\%. This is about twice the window-to-floor area usually used in single-family houses. Even so, the overall thermal indoor environment is good, due to the special attention given to solar control using dynamic solar shading and ventilative cooling by natural stack ventilation through the use of roof windows [19]. Another example is the design of a Danish passive house [20] in which the glazing area was selected to provide a daylight factor of $2 \%$ all the way to the back of primary rooms. Here, however, there were problems with overheating because no solar control of any kind was provided [21].

We believe that the establishment of cost-effective and successful window solutions in 'nearly zero-energy' buildings requires more knowledge about the link between various window design parameters and their combined effect on energy consumption, daylighting and thermal indoor environment for rooms with different geometries. In this paper we wish to contribute to this knowledge by studying the effect of glazing-to-floor ratio, orientation, and glazing properties such as U-value, g-value and light transmittance in side-lit rooms with different geometries representing Danish 'nearly zero-energy' single-family houses. The results are presented in terms of diagrams, exemplifying an approach by which window solutions with minimum space heating demand can be chosen within a solution space defined by targets for daylighting and thermal comfort.

\section{Methodology}

\subsection{Simulation process and model description}

Daylighting was computed independently from energy consumption and thermal indoor environment. For the calculation of energy consumption and thermal environment, the building simulation tool EnergyPlus (version 7.2) [22] was used in combination with the tool jEPlus 1.4 $[23,24]$, which is a parametric shell program designed for use with EnergyPlus. EnergyPlus has been widely validated and is an acknowledged simulation tool that uses the heat balance model to predict thermal performance in buildings. EnergyPlus allows for hourly calculation of space heating demand and operative temperatures based on detailed treatment of solar radiation. Analyses with regard to daylighting were carried out using the RADIANCE-based daylighting analysis tool DAYSIM (version 3.1) [25]. The targets and evaluation criteria used throughout this paper are further explained in Section 2.2 Evaluation criteria. 


\subsubsection{Room geometry}

To study the relationships between window size, orientation, U-value, g-value and visual light transmittance, the investigations were made at room level. This made it possible to investigate how window size, orientation and geometry affect the performance in a transparent way. A total of 9 different room dimensions with varying width-to-depth ratios were used, see Table 1.

Table 1: Room dimensions and width-to-depth ratio for each room geometry.

\begin{tabular}{|c|c|c|c|c|c|c|c|c|c|c|}
\hline & \multicolumn{2}{|l|}{$2: 1$} & \multicolumn{2}{|l|}{$1.5: 1$} & \multicolumn{2}{|l|}{$1: 1$} & \multicolumn{2}{|l|}{$1: 1.5$} & \multicolumn{2}{|l|}{$1: 2$} \\
\hline & $\mathrm{W}(\mathrm{m})$ & $\mathrm{D}(\mathrm{m})$ & $\mathrm{W}(\mathrm{m})$ & $\mathrm{D}(\mathrm{m})$ & $\mathrm{W}(\mathrm{m})$ & $\mathrm{D}(\mathrm{m})$ & $\mathrm{W}(\mathrm{m})$ & $\mathrm{D}(\mathrm{m})$ & $\mathrm{W}(\mathrm{m})$ & $\mathrm{D}(\mathrm{m})$ \\
\hline Large rooms & 8 & 4 & 6 & 4 & & & 4 & 6 & 4 & 8 \\
\hline Base case & & & & & 4 & 4 & & & & \\
\hline Small rooms & 5.3 & 2.7 & 4 & 2.7 & & & 2.7 & 4 & 2.7 & 5.3 \\
\hline
\end{tabular}

Rooms were modelled with ceiling, floor and one façade exposed to the outside climate to represent rooms in typical Danish single-family houses, which are characterised by their rectangular shape and one-storey floor plan. Room height was set to $2.5 \mathrm{~m}$ and a wall thickness of $0.5 \mathrm{~m}$ was used. No external obstructions were taken into account.

\subsubsection{Building specifications}

Construction and building system properties for the various room geometries were selected to comply with future requirements for the annual energy consumption in 'nearly zero-energy' houses in Denmark [26]. These requirements are in form of a target energy frame, stating a maximum yearly heating demand (see Section 2.2 Evaluation criteria). Table 2 contains input data on construction, building system properties, and internal loads for the simulation model. The heating set-point and design values for internal gains were chosen in accordance with standard practice in Denmark [27]. Heating power to achieve the heating set point was assumed infinite by using the ideal loads air system in EnergyPlus [28]. Mechanical ventilation was set to $0.6 \mathrm{~h}^{-1}$ while infiltration was set to $0.05 \mathrm{~h}^{-1}$ for the whole year. Natural ventilation through opening of windows, referred to as venting, was set to $3 \mathrm{~h}^{-1}$ outside the heating season. This corresponds to the maximum air flow rate possible for single-sided natural ventilation by automated opening of windows [27]. To ensure a good thermal indoor environment, solar protection should be integrated early in the design [21, 29], in addition to venting. Recent findings [30, 31] have indicated that the importance of a high g-value for reducing space heating demand for southoriented rooms in 'nearly zero-energy' buildings is limited even in the Danish climate, which makes the cost-efficiency of dynamic shading solutions debatable. Therefore, in this research work, we considered g-value to reflect the use of permanent solar shadings (glazing with solar control coating) instead of using dynamic shading solutions. 
Table 2: Input values defining the thermal simulation model with respect to construction properties, and system and internal loads.

\begin{tabular}{ll}
\hline Construction properties & \\
U-value wall $^{11}$ & $0.10 \mathrm{~W} / \mathrm{m}^{2} \mathrm{~K}$ \\
U-value roof & \\
U-value floor & \\
& $0.08 \mathrm{~W} / \mathrm{m}^{2} \mathrm{~K}$ \\
System and internal loads & $0.09 \mathrm{~W} / \mathrm{m}^{2} \mathrm{~K}$ \\
Heating set point & \\
Venting set point & $20^{\circ} \mathrm{C}$ \\
Infiltration rate & $23^{\circ} \mathrm{C}$ \\
Venting rate (maximum) & $0.05 \mathrm{~h}^{-1}$ \\
Mechanical ventilation rate & $3 \mathrm{~h}^{-1}$ \\
Efficiency of heat recovery & $0.6 \mathrm{~h}^{-1}$ \\
Internal gains from people & 0.9 \\
Internal gains from equipment & $1.5 \mathrm{~W} / \mathrm{m}^{2}$ \\
and lighting & $3.5 \mathrm{~W} / \mathrm{m}^{2}$ \\
\hline
\end{tabular}

1) Includes linear heat losses

For daylight calculations, a diffuse reflectance of $70 \%$ was assumed for walls and ceiling and a reflectance of $30 \%$ for floors.

\subsubsection{Parameter variations}

Glazing-to-floor ratio, orientation, and glazing properties such as U-value, g-value and visual transmittance were varied as indicated in Table 3 for each of the room geometries. The window frame considered for the investigations has a thermal transmittance of $0.9 \mathrm{~W} / \mathrm{m}^{2} \mathrm{~K}$ and a width of $5 \mathrm{~cm}$, which was kept the same for all investigations.

Table 3: Variables used for parameter analyses.

\begin{tabular}{ll}
\hline Parameter & Variable \\
\hline Orientation & $\mathrm{N} / \mathrm{S}$ \\
Glazing-to-floor ratio & $(\%)$ \\
Glazing U-value $\left(\mathrm{W} / \mathrm{m}^{2} \mathrm{~K}\right)$ & $10 / 15 / 20^{2)} / 25^{3)} / 30 / 35$ \\
Glazing g-value $(-)$ & $0.3 / 0.5 / 0.7 / 0.9$ \\
Light transmittance $(-)$ & $0.1 / 0.2 / 0.3 / 0.4 / 0.5 / 0.6 / 0.7$ \\
\hline
\end{tabular}

1) Based on internal floor area.

2) Glazing-to-floor ratios greater than $20 \%$ were not investigated for the room with geometry $4 \mathrm{~m} \times 8 \mathrm{~m}$.

3) Glazing-to-floor ratios greater than $25 \%$ were not investigated for the room with geometry $4 \mathrm{~m} \times 6 \mathrm{~m}$.

For the different glazing-to-floor ratios, the glazing height was kept constant at $1.5 \mathrm{~m}$ while the glazing width was varied. Windows were placed as high in the façade as possible for optimal diffuse daylight access. Depending on the room geometry, rooms were side-lit by 1 to 4 windows. A consistent relationship between the off-set from side walls and off-set between windows was used to ensure an optimal daylight distribution. Figure 1 illustrates the variation in glazing-tofloor ratio for a $4 \mathrm{~m} \times 4 \mathrm{~m}$ room. 

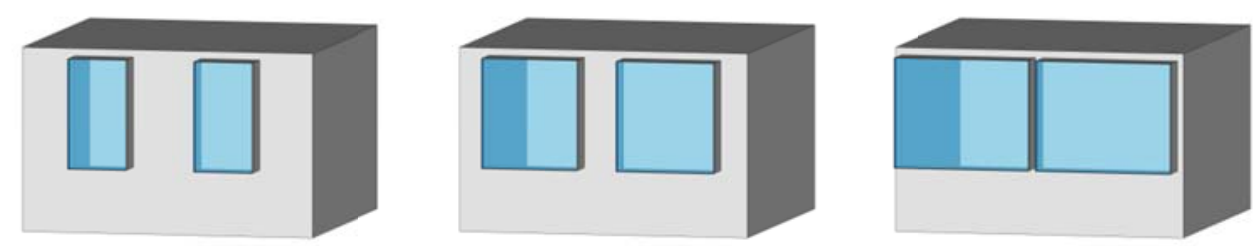

Figure 1: Illustration of glazing-to-floor-ratio for a $4 \mathrm{~m}$ x $4 \mathrm{~m}$ room. From left to right: Glazingto-floor ratio of $15 \%, 25 \%$ and $35 \%$.

\subsubsection{Weather data}

The study considered rooms with different geometries for single-family houses located in Copenhagen, Denmark. This location in the northern part of continental Europe (latitude 55.6 $6^{\circ}$ and longitude $-12.7^{\circ}$ ) represents a temperate coastal climate with rather small temperature differences between summer and winter and low to medium access to daylight and solar radiation on an annual basis. Weather data from the Danish Reference Year [32] was used for the calculations.

\subsection{Evaluation criteria}

The link between various window design parameters and their combined effect on energy, daylighting and thermal indoor environment can be assessed using different evaluation criteria. However, several dilemmas exist in finding suitable evaluation criteria [33-35]. Where different evaluation criteria are used to assess a single aspect of the same problem, this can lead to multiple valid solutions. For example, energy consumption can be quantified by evaluation of consumption for both heating, cooling, lighting, ventilation energy etc. Since the tradition for mechanical space cooling is limited in Denmark due to the climate, energy consumption was evaluated based on the space heating demand alone in $\mathrm{kWh} / \mathrm{m}^{2}$ per year. This annual space heating demand was calculated based on the hourly simulation results for space heating demand from EnergyPlus. The parameter variations for glazing-to-floor ratio and different window properties indicated in Table 3 will give a variation in results. Combinations of parameters that result in an annual space heating demand of $13 \mathrm{kWh} / \mathrm{m} 2$ or less can be considered suitable for reaching the targeted energy frame as defined in the Danish Building Code.

The thermal indoor environment was considered a boundary condition restricting possible window solutions. Different criteria and methods can be used for evaluation of thermal indoor environment. The thermal adaptive comfort method is currently being used as a new way to evaluate thermal indoor environment, but could benefit from further research [36]. We evaluated thermal indoor environment based on the thermal comfort requirements in the Danish building code for nearly-zero residential buildings [26]. The requirements state that to have a comfortable indoor environment without overheating, no more than 100 hours where the operative temperature exceeds $26^{\circ} \mathrm{C}$ should be allowed. The total number of hours with operative temperatures above $26^{\circ} \mathrm{C}$ was found based on evaluation of hourly results from EnergyPlus. If the number of hours with operative temperatures above $26^{\circ} \mathrm{C}$ exceeds 100 hours per year, this is referred to as overheating. 
The methodology and targets for the evaluation of daylighting in residential buildings are less clearly defined. For offices, a daylight factor of $2 \%$ is required in the working plane, but for nearly-zero energy residential buildings, the Danish building code only requires a minimum glazing-to-floor ratio of $15 \%$ in primary rooms when side-lit windows with a light transmittance of 0.75 are used [36]. If the light transmittance is lower, the glazing-to-floor ratio should be increased proportionally. Moreover, electricity consumption for artificial lighting is not included in the target for primary energy consumption in residential buildings. For these reasons and the less obvious usage and occupancy in residential buildings, daylighting was evaluated as an independent performance parameter, rather than expressed in terms of a reduction in energy used for artificial lighting. Provided that rooms are designed for a high daylight performance with regard to comfort and health, we considered the potential electricity savings for artificial lighting a question of control systems and the usage of the building, rather than of window design. Furthermore, it was not the aim to investigate visual discomfort. Instead, it was assumed that users can draw curtains to control glare, or adapt to glare by moving around in the space. In the following, we present a target and methodology for the evaluation of daylighting.

\subsubsection{Target and methodology for evaluation of daylighting}

We selected target and methodology for the evaluation of daylighting with reference to the ongoing discussions on how European daylight standards can be upgraded in a way that approaches climate-based daylight modelling (CBDM), which provides daylight predictions under realistic sun and sky conditions based on available weather data [37]. Over the last decade, research in the field of daylighting has discussed the shortcomings of the daylight factor method [37, 38]. The daylight factor is calculated under standard CIE overcast sky conditions, so variations in daylight over time for different climates, locations and building orientations are not considered. Furthermore, the use of daylight factor requirements can sometimes result in conflicts between visual and thermal comfort requirements [39]. However, the daylight factor method is still used in guidelines and standards [17, 26, 40]. Moreover, the use of CBDM requires expert knowledge or expert simulation tools, while the daylight factor method uses existing tools and requires less computation power.

As a transition between the current practice of using the daylight factor method and the use of CBDM, Mardaljevic and Christoffersen [41] suggested the use of a slight modification to the daylight factor method that creates connectivity to the diffuse daylight access at a specific location, referred to in this paper as a climate-dependent approach. On the assumption that the diffuse daylight access follows the same graduation in brightness as the CIE overcast sky model, a target daylight factor $\left(D F_{\text {target }}, \%\right)$ for various locations can be derived based on the target for median illuminance indoors $\left(E_{\text {target }}, l x\right)$ and the median diffuse illuminance available outdoors ( $\left.E_{\text {median diffuse }}, l x\right)$ during daylight hours:

$$
D F_{\text {target }}=E_{\text {target }} / E_{\text {median, diffuse }}
$$

with $E_{\text {median,diffuse }}$ calculated as the cumulative availability of diffuse illuminance from standardized climate files during daylight hours and with daylight hours defined as the hours from sunrise to sunset ( solar altitude $\geq 0^{\circ}$ ). 
When $E_{\text {target }}$ is set to 300 lux, which is considered adequate by most building users, the target daylight factor in Copenhagen is calculated to $2.11 \%$ [41]. In this study, the final daylight access of the different room geometries was evaluated as the achievement of 300 lux (or $\mathrm{DF}_{\text {target }} 2.11 \%$ ) across $50 \%$ of the work plane. Since the median of the outdoor diffuse illuminance ( $E_{\text {median,diffuse }}$ ) is used for the calculation of this achievement, this means that, for half of the daylight hours in a year, half of the surface of the horizontal work plane receives 300 lux or more. In contrast to the use of an average daylight factor, this provides information about the spatial distribution of daylight in the different rooms and ensures that daylighting in the different rooms is not only evaluated based on their predicted occupied period, due to the choice of the daylight hours as the evaluation period. However, this is not a fully climate-based approach and cannot be used as a measure for equal daylight availability for south- and north-oriented rooms over time under realistic sky conditions. On the other hand, because the climate-dependent methodology is based on overcast sky conditions, it does ensure that a sensor-point that reaches the target daylight factor (DF target) will receive a minimum of 300 lux in 50\% of the daylight hours on an annual basis. The spatial distribution of the daylight target was evaluated for a grid of sensor points with a mask width of $0.2 \mathrm{~m}$ distributed over the surface of the horizontal work plane at $0.85 \mathrm{~m}$ above floor level.

\subsection{Coupling between energy consumption and targets for daylighting and thermal comfort}

To obtain useful information about the relationship between the various window design parameters and their effect on space heating demand, thermal indoor environment and daylighting, the results for each of these parameters are presented in the same graphical illustration. For each room geometry investigated, space heating demand was plotted in a contour plot as a function of glazing-to-floor ratio and g-value for north and south orientations separately. The combinations of glazing-to-floor ratio and g-value at which indoor temperatures were above $26^{\circ} \mathrm{C}$ for more than 100 hours were plotted as a boundary indicating overheating on the contour plot, see Figure 2.

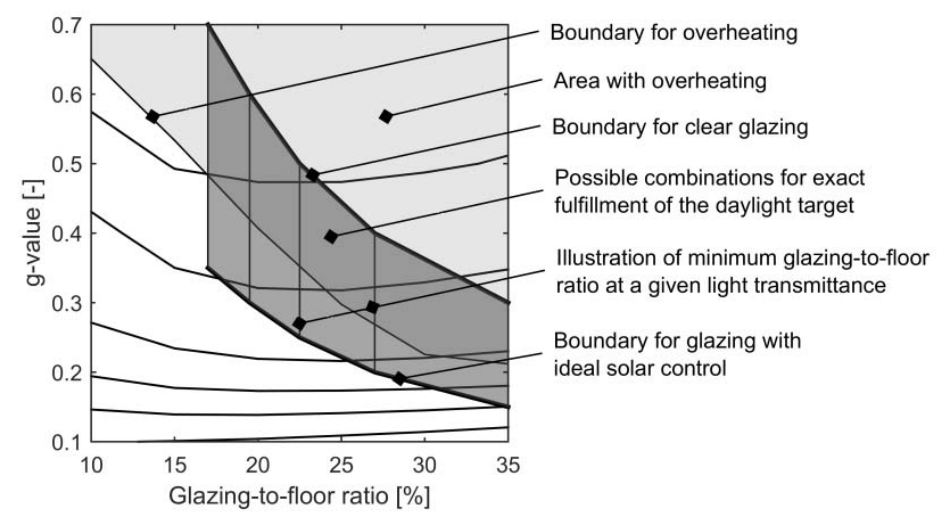

Figure 2: Conceptual illustration of contour plot of space heating demand for various g-values and glazing-to-floor ratios, indicating boundaries for overheating and daylighting. 
The boundary for daylighting at different combinations of glazing-to-floor ratio and g-value was established through the relationship between g-value and light transmittance. This relationship, also known as the 'daylighting efficiency' of glazing, varies for different glazing products. However, due to physical limitations, light transmittance is at maximum twice the solar transmittance (daylight efficiency 2). This characterizes glazings with an ideal solar control and serves as a lower limit to illustrate daylight availability. The upper limit was set to represent a clear glazing that is advantageous in situations where a large amount of solar gain is beneficial. We chose to define this boundary as the case where the light transmittance equals the solar transmittance (daylight efficiency 1). The minimum glazing-to-floor ratio that is needed for the different light transmittances to fulfil the daylight target can then be illustrated as vertical lines ranging from a solar glazing with a g-value as low as possible, to a clear glazing with g-value as high as possible. Existing products on the market can be found within this range of different daylight efficiencies. However, to fulfil targets for both daylighting and thermal comfort, only products above the limit for daylighting reached with ideal solar control glazing and below the boundary for overheating should be selected. This solution space can then also be used to choose a window design with the lowest space heating demand that fulfils targets for both daylighting and thermal comfort.

\section{Results}

\subsection{Effect of U-value, g-value and glazing-to-floor ratio}

Before discussing the full solution space defined by targets for daylighting and thermal comfort, we look into the effect of glazing U-value, g-value and glazing-to-floor ratio on space heating demand. Results are illustrated in Figure 3 for the base case, a room with dimensions of $4 \mathrm{~m}$ by $4 \mathrm{~m}$, but also apply to the other geometries. For the variables considered, the results show that Uvalue has only marginal effect on thermal comfort. On the contrary, space heating demand, as well as the best choice of glazing-to-floor ratio and g-value to reduce space heating demand, is to a high degree determined by glazing U-value. Orientation is also important in this connection.

Where in general it can be observed that sufficient access to solar gains can reduce space heating demand significantly, it was found in south-oriented rooms that there is an upper limit for energy savings and the amount of solar gains that can be utilized. When studying the g-value, Figure 3 shows that the ability to utilise solar gains varies across $U$-value, but for U-values of $0.5 \mathrm{~W} / \mathrm{m}^{2} \mathrm{~K}$ and below, a relatively pronounced stagnation in the energy savings achieved by increasing the gvalue can be observed at g-values as low as $0.3-0.4$. For the U-values $0.7-0.9 \mathrm{~W} / \mathrm{m}^{2} \mathrm{~K}$, the stagnation occurs at slightly higher g-values, but for g-values above 0.5 , increasing the g-value further will reduce space heating demand by less than $1 \mathrm{kWh} / \mathrm{m}^{2}$. In north-oriented rooms, where space heating demand is higher, the benefits of high g-values for reducing space heating demand decrease with lower U-values and with higher g-values, but in general the importance of a high gvalue remains significant for the whole range of variables investigated. 

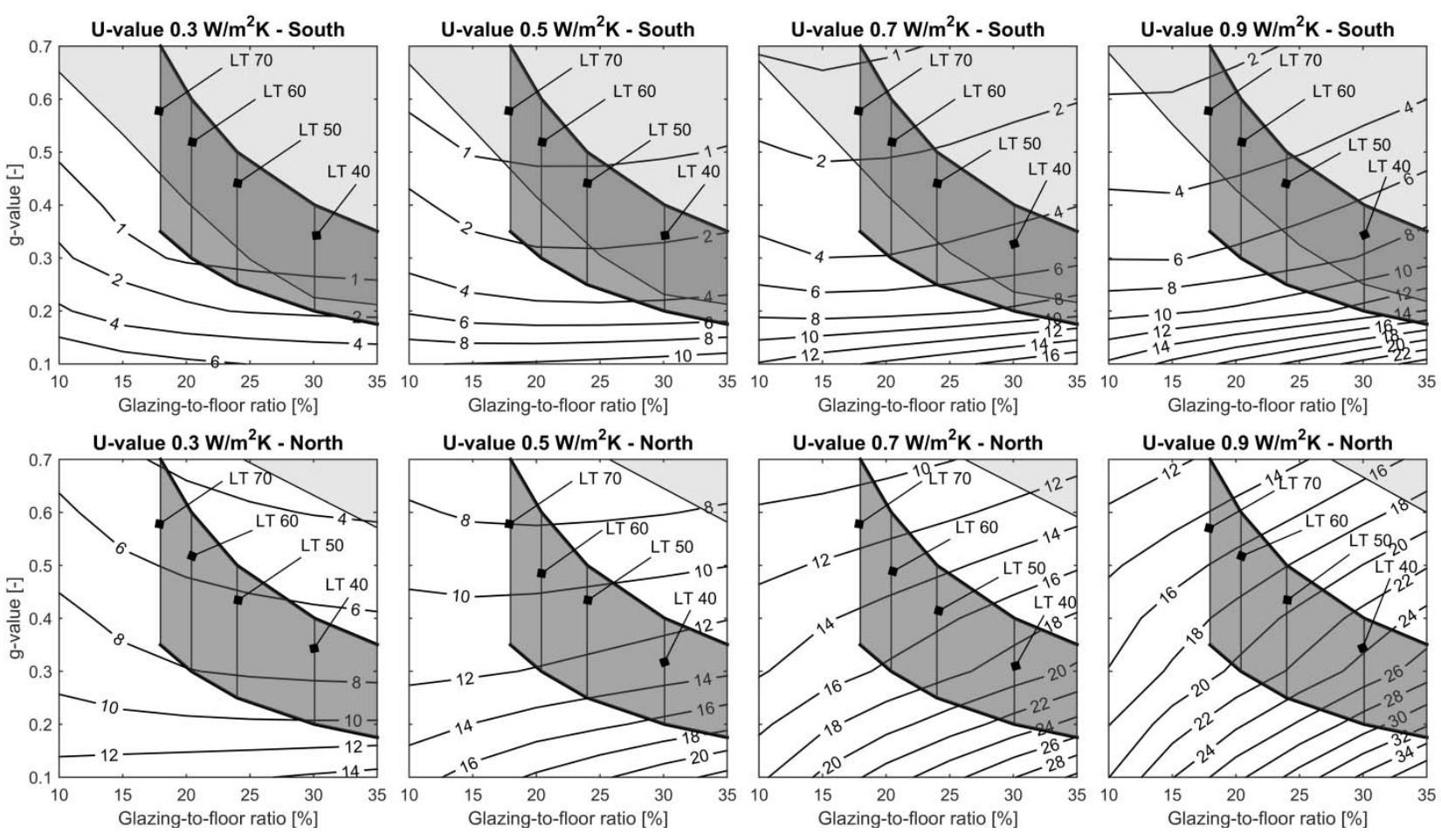

Figure 3: Contour plot of space heating demand for various $g$-values and glazing-to-floor ratios, indicating overheating and the specified daylight target for a room with dimensions of $4 m \times 4 m$ and for different glazing $U$-values.

Considering glazing-to-floor ratio, an optimum glazing-to-floor ratio of approximately $15-20 \%$ can be found in both north- and south-oriented rooms. For high glazing U-values in southoriented rooms, larger glazing-to-floor ratios increase space heating demand, while for glazing Uvalues below $0.5 \mathrm{~W} / \mathrm{m}^{2} \mathrm{~K}$ larger glazing-to-floor ratios can be chosen freely with respect to space heating demand. This indicates that the amount of solar gains that can be utilised in wellinsulated buildings can only outweigh the additional heat losses that occur with larger glazing-tofloor ratios when U-values are low. These findings are in contrast with existing guidelines and current practice for window design where high g-values and large glazing-to-floor ratios in southoriented rooms are recommended.

Similar tendencies can be found for the lower U-values in north-oriented rooms. This means that it could be possible to achieve a window design with a neutral (or even positive) energy balance also in north-oriented rooms when U-values are sufficiently low.

\subsection{Solution space and daylighting for different geometries}

We now discuss the solution space and daylight achievement for rooms with different geometries. As an example, Figure 4 illustrates the solution space for two different room geometries with width-to-depth ratios of 1:1.5 and 1.5:1 for a glazing U-value of $0.5 \mathrm{~W} / \mathrm{m}^{2} \mathrm{~K}$. The same trends can, however, also be extended to geometries with width-to-depth ratios of 1:2 and 2:1 and the other glazing $U$-values investigated in this paper. 

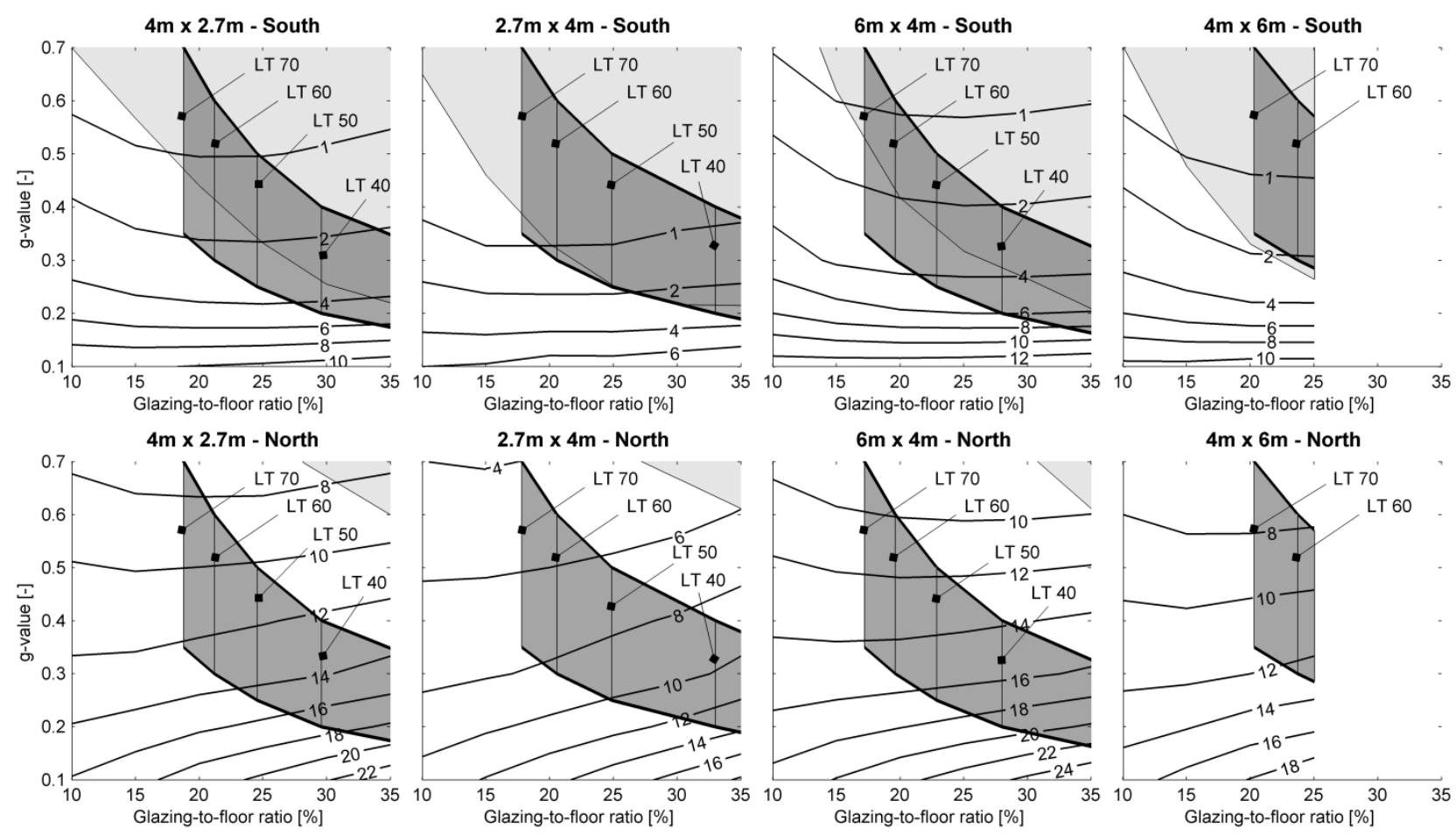

Figure 4: Contour plot of space heating demand for various $g$-values and glazing-to-floor ratios, indicating overheating and the specified daylight target for two different room sizes with a widthto-depth ratio of 1:1.5 and 1.5:1 and for a glazing $U$-value of $0.5 \mathrm{~W} / \mathrm{m}^{2} \mathrm{~K}$.

Results show that the solution space for which both thermal comfort and daylight conditions are satisfactory is considerably larger for north-oriented rooms than for south-oriented rooms. Furthermore, comparison of results for the different geometries shows that small deep geometries are preferable from the perspective of space heating demand in both north- and south-oriented rooms, while wide rooms with a shallow depth are preferable for daylighting. To achieve the same daylight access in deep rooms as in wide rooms with the same floor area, a larger glazingto-floor ratio is generally needed. This will result in increased space heating demand, especially when high U-values are used, which could outweigh some of the benefits of deep rooms in terms of energy consumption.

With regard to room geometry, it was also found that, in deep or very narrow south-oriented rooms, either daylighting or the thermal comfort is compromised when a window design is chosen. To achieve the daylight target without overheating in other south-oriented rooms, windows have to be dimensioned for nearly exact fulfillment of the daylight target, and solarcoated products with close to ideal daylight efficiency are needed. This is also illustrated in Figure 5. Figure 5 indicates the glazing-to-floor ratios that can be used in combination with clear glazing or glazing with ideal solar control (see Section 2.3) without resulting in overheating. The glazing-to-floor ratios needed to achieve the specified daylight target for each light transmittance $(0.5-0.7)$ are also illustrated. 


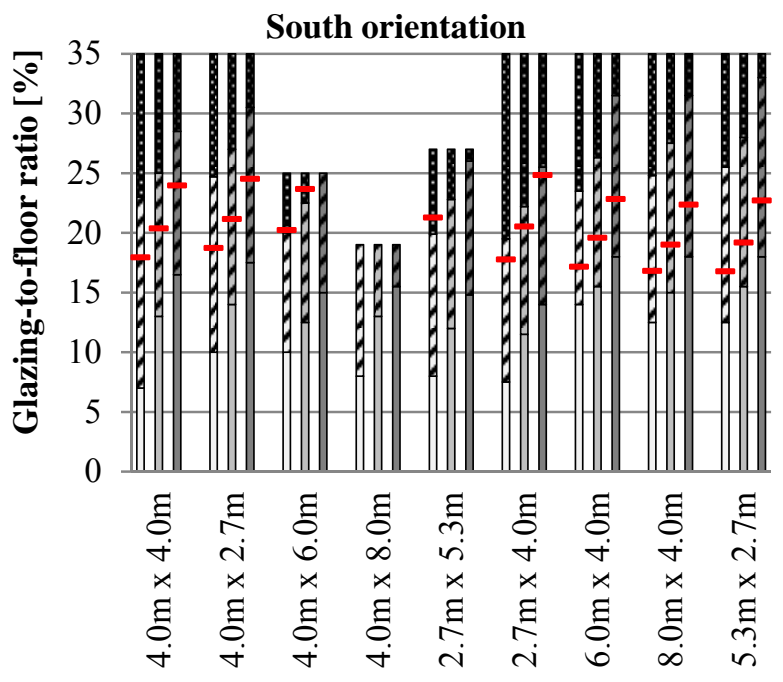

$\square$ Clear glazing, LT 0.5

$\square$ Clear glazing, LT 0.7

๑ Solar control glazing, LT 0.6

Physically possible, but overheating

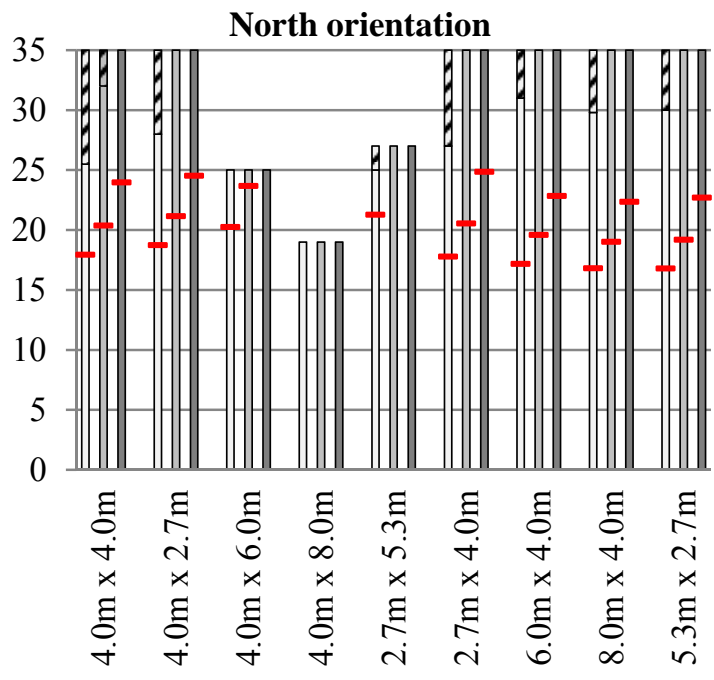

$\square$ Clear glazing, LT 0.6

\ Solar control glazing, LT 0.5

$\square$ Solar control glazing, LT 0.7

-DF target

Figure 5: Indication of glazing-to-floor ratios and glazing types that can be used to achieve the daylight target (DF target) without overheating for light transmittances of 0.7, 0.6 and 0.5 for various room geometries.

For north-oriented rooms, none of the geometries experience problems with overheating before achieving the daylight target, even when clear glazings are used. However, in deep rooms facing north, for example a room with dimensions of $4 \mathrm{~m} \times 8 \mathrm{~m}$, the target for daylight cannot be met due to the physical limitations of the geometry. When considering the geometries that can achieve the daylight target without overheating, glazing-to-floor ratios of approximately $17-25 \%$ are needed to achieve the daylight target for light transmittances of $0.7-0.5$ in both north- and south-oriented rooms. This is close to the recommendations in the Danish building code, which states that a glazing-to-floor ratio of $15 \%$ is needed for a light transmittance of 0.75 [26].

Figure 5 also shows that the daylight target in deep and narrow rooms can only be achieved for light transmittances of at least $0.6-0.7$, but in general glazing products ranging from high to low light transmittance can be used if they are combined with the right glazing-to-floor ratio. However, glazing types with high light transmittances and as high g-values as possible generally allow for a lower space heating demand than products with lower light transmittances and as high g-values as possible.

The range of available g-values in south-oriented rooms is slightly larger for high light transmittances, than for low transmittances. Glazing products with low U-values and high light transmittances also provide the best fit between the maximum g-values for prevention of overheating and the g-values at which the energy savings start to stagnate, see Figure 4. Furthermore, high light transmittances allow the use of smaller glazing-to-floor ratios for daylighting (within the range of 17-25\%). This could be an advantage in cases where less glazing is desirable due to cost and will also allow for the lowest possible space heating demand if high U-values are used. In north-oriented rooms, small glazing-to-floor ratios and high light 
transmittances are also preferable for high glazing U-values. At low glazing U-values, flexibility in choosing a window design increases and larger glazing-to-floor ratios could be used, provided that clear glazings with high g-values are chosen in north-oriented rooms to reduce space heating demand.

\section{Discussion}

The parametric analyses and the charts illustrating the solution space in this study invite for an open discussion of the link between various design and performance parameters as well as the possibilities and potential conflicts related to façade window design in 'nearly zero-energy' houses. For example, the charts highlight potential design conflicts in deep or narrow southoriented rooms, because either thermal comfort or daylighting is compromised when only façade windows are used. Conflict situations like this can lead to a discussion on the performance parameters and the chosen targets in the charts, but could also indicate the need for investigations on other design possibilities, e.g. the use of roof windows in deep south-oriented rooms, or alternative solutions such as increased venting (for example using cross ventilation) could be considered. In principle, all the performance parameters and the chosen targets can be tested for sensitivity to e.g. different insulation thicknesses, different user patterns and adaptive models for thermal comfort, different ventilation systems and air change rates, and different daylight targets. The solution space will then also have different characteristics.

In the Danish climate, it was possible to have a window design for certain room geometries fulfilling the targets for daylighting and thermal comfort without the use of mechanical cooling, but with the use of permanent solar shading and with a maximum venting rate of $3 \mathrm{~h}^{-1}$. In this connection, further studies related to other climates and performance parameters should be considered. For example, in warmer climates, where mechanical cooling might be needed to avoid overheating, the value of daylighting compared to the energy used for cooling may give rise to several discussions, such as the relative weight assigned to the performance parameters and targets. It might then also be relevant to consider whether window sizes should be dimensioned based on realistic sun and sky conditions.

The target used for daylight evaluation in our study was chosen to reflect a specific location, but does not take into account realistic sun and sky conditions because it is based on evaluation of the daylight target under a CIE overcast sky. As a result, glazing-to-floor ratios for providing enough daylighting were found to be the same for both north and south-oriented rooms. However, due to prevention of overheating in south-oriented rooms, more flexibility with regard to the choice of window size and geometries was found for north-oriented rooms than for south-oriented rooms. For the two orientations to have comparable daylighting over time under realistic sun and sky conditions either the glazing-to-floor ratio towards the south must be decreased or the glazing-tofloor ratio towards the north must be increased. As the risk of overheating is close to insignificant in north-oriented rooms, it could be argued that slightly larger glazing-to-floor ratios should generally be used here than in south-oriented rooms when low U-values are used. In this case, a climate-based approach for the evaluation of daylight may be needed. The use of such an approach might also increase the choice of room geometry. Investigations by Ko [6], taking into 
account a clear sky and sun at equinox at noon for different locations, showed for example that a lower sun position in winter results in more daylight penetration deeper in a room. However, further studies on visual comfort in south-oriented rooms and the effects of daylighting on human health, comfort and well-being, will be needed to determine how comparable targets for northand south-oriented rooms can be set in residential buildings. At this stage, the use of a target daylight factor taking into account building location might be considered a valid approach because architects and designers do not always have the knowledge or expert tools to calculate the available daylight using CBDM in the early design phases.

\section{Conclusions}

The relationships between various façade window parameters (glazing-to-floor ratio, orientation and glazing properties) and how these affect energy consumption, thermal indoor environment and daylighting were studied for different side-lit room geometries representing Danish 'nearly zero-energy' single-family houses. With regard to daylight performance, a target daylight factor taking into account building location was used. Charts illustrating a solution space for space heating demand defined by targets for daylighting and thermal comfort were used to discuss the effect of various window parameters. These charts can also be used to select a window design that is beneficial in terms of all three performance parameters. The main results showed that:

- The use of high g-values and large glazing-to-floor ratios in south-oriented rooms to reduce space heating demand is less important than traditionally believed in wellinsulated houses. Findings in this paper showed that g-values above 0.3-0.4 have limited effect on decreasing the space heating demand. Furthermore, glazing U-values between $0.3-0.5 \mathrm{~W} / \mathrm{m}^{2} \mathrm{~K}$ are needed before the use of very large glazing-to-floor ratios may lead to reductions in space heating demand.

- In order to reach the daylight target without overheating in south-oriented rooms, windows have to be carefully dimensioned on the basis of the daylight target and solarcoated products with close to ideal daylight efficiency are needed. For high light transmittances and low U-values, the choice of g-value from the perspective of space heating demand corresponds well with the g-value for prevention of overheating by use of solar-coated products with close to ideal daylight efficiency. Permanent solar shading solutions, such as solar-coated glazing products with some degree of daylight efficiency, could therefore be used as robust, user-friendly and cost-effective alternatives to dynamic solar shading devices to reduce overheating in south-oriented rooms. Nevertheless, one should keep in mind that some types of solar-coating can give a slight tint to the glass, which might be undesirable.

- In north-oriented rooms, high g-values are recommended to reduce space heating demand. As the risk of overheating is small in north-oriented rooms, the combination of g-value and glazing-to-floor ratio can be chosen relatively freely to fulfill the target for daylighting. At low U-values, this flexibility in north-oriented rooms also means that a window design with large-glazing-to-floor ratios can be used without having a more negative impact on space heating demand than a design with smaller glazing-to-floor ratios. 
- In deep or narrow south-oriented rooms, either thermal comfort or daylighting is compromised with the use of permanent solar shading. Greater flexibility with regard to geometry was found in north-oriented rooms, but this is when the daylight availability for both orientations is evaluated under a standardized overcast sky, without taking orientation or direct sun into account.

\section{Acknowledgements}

The authors would like to thank VELUX A/S and the Bjarne Saxhofs Foundation for their financial support for this research.

\section{References}

[1] European Union, Directive 2010/31/EU of the European Parliament and of the Council of 19 May 2010 on the Energy Performance of Buildings (recast), Official Journal of the European Union, 18/06/2010, Strasbourg, France, 2010.

[2] Susorova, I., Tabibzadeh, M., Rahman, A., Clack, H.L., Elnimeiri, M. The effect of geometry factors on fenestration energy performance and energy savings in office buildings. Energy and Buildings 57 (2013) 6-13.

[3] Ghisi, E., Tinker, J.A. An Ideal Window Area concept for energy efficient integration of daylight and artificial light in buildings. Building and Environment 40 (2005) 51-61.

[4] Lee, J.W., Jung, H.J., Park, J.Y., Lee, J.B., Yoon, Y. Optimization of building window system in Asian regions by analyzing solar heat gain and daylighting elements. Renewable Energy 50 (2013) 522-531.

[5] Motuziene, V., Juodis, E.S. (2010) Simulation based complex energy assessment of office building fenestration. Journal of Civil Engineering and Management 16:3, 345-351.

[6] Ko, D-H. Fenestration guideline for energy and daylight efficiency: Evaluation and prediction of performance in office buildings. Doctoral dissertation, Illinois Institute of Technology, Chicago, USA, 2009.

[7] Li, D.H.W., Lo, S.M., Lam, J.C., Yuen, R.K.K. (1999) Daylighting Performance in Residential Buildings, Architectural Science Review 42:3, 213-219.

[8] Li, D.H.W., Wong, S.L., Tsang, C.L., Cheung, G.H.W. A study of the daylighting performance and energy use in heavily obstructed residential buildings via computer simulation techniques. Energy and Buildings 38 (2006) 1343-1348.

[9] Wong, N.H., Istiadji, A.D. Effect of external shading devices on daylighting penetration in residential buildings. Lighting Research and Technology, 36:4 (2004), 317-333.

[10] Inanici, M.N., Demirbilek, F.N. Thermal performance optimization of building aspect ratio and south window size in five cities having different climatic characteristics of Turkey. Building and Environment 35 (2000) 41-52.

[11] Hassouneh, K., Alshboul, A., Al-Salaymeh, A. Influence of windows on the energy balance of apartment buildings in Amman. Energy Conversion and Management 51 (2010) 1583-1591. 
[12] Gasparella, A., Pernigotto, G., Cappelletti, F., Romagnoni, P., Baggio, P. Analysis and modelling of window and glazing systems energy performance for a well-insulated residential building. Energy and Buildings 43 (2011) 1030-1037.

[13] Jaber S., Ajib, S. Optimum, technical and energy efficiency design of residential building in Mediterranean region. Energy and Buildings 43 (2011) 1829-1834.

[14] Persson, M-L., Roos, A., Wall, M. Influence of window size on the energy balance of low energy houses. Energy and Buildings 38 (2006) 181-188.

[15] Andersen, M., Mardaljevic, J., Lockley, S.W. A framework for predicting the non-visual effects of daylight - Part I: photobiology-based model. Lighting Research and Technology 44: (2012) 37-53.

[16] Active House Alliance. Active house - A vision. http://www.activehouse.info/about-activehouse/active-house-vision (accessed 04.08.13).

[17] Active House Alliance. Active house - The specifications. Second ed., Brussels, Belgium, 2013.

[18] Model Home 2020. http://www.velux.com/Sustainable_living/Model_Home_2020 (accessed 04.08.13).

[19] Foldbjerg, P., Asmussen, T. Using ventilative cooling and solar shading to achieve good thermal environment in a Danish Active House. The REHVA European HVAC Journal, vol. 50 no. 3 (2013) 36-42.

[20] Komforthusene. http://komforthusene.dk/ (accessed 04.08.13).

[21] Larsen, T.S. Vurdering af indeklimaet i hidtidigt lavenergibyggeri - med henblik på forbedringer i fremtidens lavenergibyggeri. DCE contract report No.100, Aalborg University, 2011 (in Danish).

[22] US Department of Energy, EnergyPlus Energy simulation software, http://apps1.eere.energy.gov/buildings/energyplus/ (accessed 02.07.13).

[23] Zhang, Y., Korolija, I. "Performing complex parametric simulations with jEPlus", SET2010

- 9th International Conference on Sustainable Energy Technologies, 24-27 August 2010, Shanghai, China.

[24] Zhang, Y. 'Parallel' EnergyPlus and the development of a parametric analysis tool, IBPSA BS2009, 27-30 July 2009, Glasgow, UK.

[25] DAYSIM, Advanced daylight simulation software. http://daysim.ning.com/ (accessed 02.07.13).

[26] Danish Energy Agency, Building Regulations 2010 Ver. 01.01.2013.

http://www.bygningsreglementet.dk/br10_03/0/42 (in Danish) (accessed 02.07.13).

[27] Aggerholm, S.O. and Grau, K.E. SBi-anvisning 213: Bygningers energibehov - Beregningsvejledning, second ed., Danish Building Research Institute, Aalborg University, 2011 (in Danish).

[28] U.S Department of Energy, EnergyPlus Engineering reference, 2013. http://apps1.eere.energy.gov/buildings/energyplus/.

[29] Peuhkuri, R. Principles and specific challenges of very low-energy houses in colder climates and corresponding residential concept houses. 2010. 
[30] Skarning, G.C.J., Svendsen, S., Hviid, C.A. Investigation and description of European buildings that may be representative for "nearly zero" energy single family houses in 2020. Proceedings of the CISBAT Conference, Lausanne, 4-6 September 2013.

[31] Vanhoutteghem, L., Svendsen, S. Modern insulation requirements change the rules of architectural design in low-energy homes. Renewable Energy 72 (2014) 301-310.

[32] Jensen, J.M., Lund, H., Design Reference Year, DRY - et nyt dansk reference år. Technical Report lfv-281., Technical University of Denmark, 1995 (in Danish).

[33] Ochoa, C.E., Aries, M.B.C., van Loenen E.J., Hensen, J.L.M. Considerations on design optimization criteria for windows providing low energy consumption and high visual comfort. Applied Energy 95 (2012) 238-245

[34] Alwaer H, Clements-Croome DJ. Key performance indicators (KPIs) and priority setting in using the multi-attribute approach for assessing sustainable intelligent buildings. Building and Environment 45 (2010) 799-807.

[35] Alanne K, Salo A, Saari A, Gustafsson S-I. Multi-criteria evaluation of residential energy supply systems. Energy and Buildings 39 (2007) 1218-26.

[36] Toftum J, Andersen RV, Jensen KL. Occupant performance and building energy consumption with different philosophies of determining acceptable thermal conditions. Building and Environment 44 (2009) 2009-2016.

[37] Mardaljevic, J. Examples of climate-based daylight modelling. Proceedings of the CIBSE National Conference, London, 21-22 March 2006.

[38] Mardaljevic, J., Heschong, L., Lee, E. Daylight metrics and energy savings. Lighting Research and Technology, 41:3 (2009), 261-283.

[39] Reinhart CF, Mardaljevic J, Rogers Z. Dynamic daylight performance metrics for sustainable building design. Leukos 3(2006) 1-25.

[40] British standard, BS8206-2:2008. Lighting for buildings - Part 2: Code of practice for daylighting. 2009.

[41] Mardaljevic, J., Christoffersen, J. A roadmap for upgrading national/EU standards for daylight in buildings. Proceedings of the CIE Centenary Conference, Paris, 15-16 April 2013. 